\title{
PENERAPAN PERMAINAN DALAM PEMBELAJARAN PADA MATAKULIAH FISIKA PERMAINAN UNTUK MENGHILANGKAN KESAN KAKU CALON GURU FISIKA
}

\author{
Dedy Hidayatullah Alarifin \\ Pendidikan Fisika FKIP Universitas Muhammadiyah Metro \\ email: dedyarifin77@gmail.com
}

\begin{abstract}
Abstrak: Mahasiswa FKIP sebagi calon guru memiliki peran penting dalam merubah pandangan peserta didik pada materi pelajaran. Untuk itu mahasiswa FKIP sebagai calon guru dipandang perlu mendapatkan bekal yang memadahi tentang pembelajaran yang menyenagkan. Sebagian besar peserta didik beranggapan bahwa fisika itu kaku dan membosankan. Kenyataan ini di pertajam dengan cara guru dalam melakukan kegiatan pembelajaran yang terkesan kaku. Pembelajaran fisika akan lebih terasa menyenangkan jika peserta didik kita arahkan dalalm proses pembelajaran dengan menggunakan permainan. Harapan dengan adanya permainan dalam pembelajaran adalah terciptanya susana yang menyenangkan sehingga menjadikan peserta didik menjadi bersemanagat dan suka terhadap mata pelajaran fisika. Dengan demikian diharapkan peserta didik akan mudah dalam memahami pelajaran fisika sehingga dapat menghasilkan luaran yang maksimal.
\end{abstract}

Kata kunci: permainan, meghilangkan kesan kaku dan calon guru fisika.

\section{PENDAHULUAN}

Menanamkan rasa suka, senang, tertarik, dan butuh kepada peserta didik merupakan salah satu kiat yang efektif untuk keberhasilan belajar peserta didik. Belajar tadak hanya dibatasi pada satu tempat, kondisi, ruang, dan waktu tertentu saja. Memang dalam belajar harus ada penjadwalan yang baik, hal ini untuk menciptakan kondisi si belajar agar lebih teratur dan menyusun informasi yang dipelajari lebih tersusun dengan baik. Kondisi ini akan memungkinkan si peserta didik tidak akan memiliki sifat ketergantungan dengan satu keadaan saja. Hal lain yang akan muncul adalah pesert didik akan lebih percaya diri dan akan mudah menyesuaikan dengan kondisi lingkungannya kelak. Untuk menciptakan kondisi belajar yang menyenangkan pesrta didik harus termotivasi untuk melakukan kegiatan belajar. Seorang pendidik memiliki peran penting dalam peraihan kesuksesan peserta didik. Banyaknya anggapan yang mengatakan bahwa guru fisika adalah orang yang kaku menjadikan susana pembelajaran menjadi lebih menegangkan. Kondisi yang demikian memang tidak dapat dihindari bahwa guru fisika memiliki kesan yang kaku. Hal ini berkaitan erat dengan mata pelajaran fisika yang identik dengan perhitunganperhitungan yang membutuhkan kecermatan, ketekunan serta penguasaan konsep yang memadahi. Kondisi ini lebih dipertajam dengan banyaknya guru yang beranggapan bahwa siswa akan mau belajar ketika siswa patuh dengan semua perintah guru. Patuhnya siswa seharusnya dapat dimaknai lain dengan rasa takutnya siswa. Kedua hal ini akan nampak sama ketika siswa melakukan kegiatan 
pembelajaran. Siswa yang takut akan terpaksa melakukan kegiatan pembelajaran. Hal ini akan menghsilkan luaran yang berbeda dengan siswa yang patuh kepada guru. Ketika siswa patuh kepada arahan guru, dapat diindikasi bahwa siswa tersebut tertarik, sayang, peduli dan menghormati guru sebagai pendidik. Ketika kita mempelajari fisika, sebenarnya kita sedang mempelajari sesuatu pelajaran yang menyenagkan. Dengan belajar fisika maka kita akan mengetahui kehdupan ini jauh lebih baik. Banyak hal-hal yang menyenagkan dalam pelajaran fisika. Semua teori yang ada dalam pelajaran fisika muncul karena pengamatan riil yang ada di lingkungan. Gabungan yang indah antar disiplin ilmu terangkai dalam pelajaran fisika. Jadi sudah selayaknya ketika guru fisika melaksanakan pembelajaran dengan cara yang menyenagkan. Permainan menurut Johan Huizinga (dalam Murtiningsih, 2013) adalah suatu perbuatan atau kegiatan sukarela, yang dilakukan dalam batas-batas ruang dan waktu tertentu yang sudah ditetapkan, menurut aturan yang sudah diterima secara sukarela tapi mengikat sepenuhnya, dengan tujuan dalam dirinya sendiri, disertai oleh perasaan tegang dan gembira, dan kesadaran lain daripada kehidupan sehari-hari. Berdasarkan definisi tersebut dapat disimpulkan bahwa permainan memiliki ciri khas, batasan, dan aturan yang mengikat yang membedakannya dengan kegiatan dalam kehidupan yang lain. Menurut Kimpraswil yang dikutip Muhammad (dalam Sigid, 2014) mengatakan bahwa definisi permainan adalah usaha olah diri (olah pikiran dan olah fisik) yang sangat bermanfaat bagi peningkatan

danpengembangan motivasi, kinerja, dan prestasi dalam melaksanakan tugas dan kepentingan organisasi dengan lebih baik. Lain halnya dengan Freeman dan Munandar (dalam Sigid, 2014) yang mendefinisikan permainan sebagai suatu aktifitas yang membantu anak mencapai perkembanganyang utuh, baik fisik, intelektual, sosial, moral, dan emosional. Menurut beberapa pendapat para ahli tersebut peneliti menyimpulkan definisi permainan adalah suatu aktifitas yang dilakukan oleh beberapa anak untuk mencari kesenangan yang dapatmembentuk proses kepribadian anak, dan membantu anak mencapai perkembangan fisik,intelektual, sosial, moral dan emosional. Fisika merupakan mata pelajaran yang terkesan kaku dan membosankan bagi siswa. Hal ini mengakibatkan rendahnya kualitas proses dan prestasi belajar. Hal ini sejalan dengan penelitian yang dilakuakn oleh Triwiyono (2011) yang menunjukkan oleh fakta dalam pembelajaran fisika motivasi belajar siswa rendah dan siswa mengalami kesulitan belajar pada mata pelajaran fisika. Oleh karena itu perlu adanya stimulus berupa permainan dalam pembelajaran fisika guna meningkatkan motovasi belajar siswa. Aspek yang terdapat dari sisi permainan dalam pembelajaran fisika antara lain aspek fisik, aspek sosial, aspek bahasa, aspek emosi dan kepribadian, aspek kognisi, aspek perkembangan kreativitas. 
Guru yang kreatif menurut Purwanto (2011) akan selalu berusaha agar materi pelajaran fisika mudah diterima, terkesan, menyenangkan, menimbulkan atau bahkan meningkatkan motivasi siswa atas model pembelajaran yang dilakukan guru. Di samping itu seorang guru atau calon guru fisika mempunyai karakter sebagai pendidik, pengajar, berjiwa sosial, welas asih pada sesama, sebagai panutan / pemberi contoh yang baik pada anak didiknya, mudah menyesuaikan pada lingkungan, bertanggung jawab, penuh pengabdian, dedikasi tinggi, peduli, dan penuh pengorbanan demi keberhasilan anak didik.

Seorang guru dan calon guru harus mampu melakukan variasi pembelajaran dan mengelola kelas. Hal ini sesuai dengan pendapat dari Mardiyono (2006) yang menyatakan bahwa keterampilan dasar mengajar adalah keterampilan dalam hal: (1) memulai dan mengakhiri pembelajaran (2) menjelaskan sesuatu

reinforcement (4) menggunakan media

(5) menyusun skenario pembelajaran

(6) mengadakan variasi pembelajaran

(7) membimbing diskusi (8) mengelola kelas (9) memotivasi bertanya, dan (10) mengevaluasi secara bertahap dan terpisah.

\section{METODE PENELITIAN}

Jenis penelitian ini adalah pengembangan dengan menggunakan Four-D models yaitu define, design, develop, dan dessiminate. Pengumpulan data menggunakan lembar pengamatan, angket dan dokumentasi. Lembar pengamatan permainan yang akan digunakan dalam pembelajaran fisika berfungsi sebagai alat mengetahui kelayakan permainan yang digunakan, lembar pengamatan untuk mengukur keterlaksanaan perkuliahan, lembar angket mahasiswa untuk mengetahui aktivitas selama perkuliahan dan respon mahasiswa terhadap permainan yang dilakukan dan proses pembelajaran, serta dokumentasi kegiatan mahasiswa dalam perkuliahan fisika permainan.

\section{HASIL DAN PEMBAHASAN}

Saat proses pembelajaran berlangsung mahasiswa merasa nyaman dengan keadaan pembelajaran yang menyenagkan. Kondisi ini terjadi karena saat proses pembelajaran dilaksanakan peneliti menyiapkan permainan disela-sela pembelajaran berlangsung. Sehingga tidak ada tekanan yang dirasakan oleh peserta didik, mahasiswa mengikuti proses pembelajaran dengan senang dan bahagia tanpa ada paksaan. Hal ini terjadi karena pembelajaran yang dilakukan sebisa mungkin membentuk keadaan pembelajaran yang menyenangkan namun tidak merusak konsentrasi, sehingga materi yang disampaikan dapat dipahami siswa secara optimal dan mendapatkan hasil pembelajaran yang sesuai dengan tujuan pembelajaran.

Penggunaan permainan dalam pebelajaran menimbulkan perasaan gembira serta membangkitkan semangat mahasiswa ini dirasa memiliki peran penting dalam melakukan kegiatan pembelajaran.

Penerapan permainan saat sebelum memulai pembelajaran, akan 
memberikan kesan yang menarik dan menyenangkan hal ini akan membagkitkan rasa ketertarikan peserta didik dalam melakukan kegiatan pembelajaran.

Permainan ditengah pembelajaran bertujuan untuk mengembalikan konsentrasi mahasiswa yang sudah menurun. Hal ini dilakukan karena mahasiswa pada pertengahan pembelajaran terlihat bosan, mengantuk dan malas. Konsentrasi terwujud dengan pengaturan lingkungan belajar, supaya siswa merasa nyaman dan rileks saat mengikuti pembelajaran. Setelah diberikan perminan dalam pembelajaran dipertengahan pembelajaran mahasiswa kembali memperhatikan materi pelajaran yang disampaikan. Pembelajaran yang menyenangkan mendorong mahasiswa untuk lebih kreatif. Mahasiswa juga mampu untuk mengungkapkan ide-ide dan gagasannya sehingga pembelajaran akan menjadi lebih hidup.

\section{KESIMPULAN}

Pemilihan pemainan dirasa sangat diperlukan, ini harus disesuaikan dengan kondisi si beajar. Selain itu juga termasuk memperhatikan tahap perkembangan peserta didik dirasa sangat penting agar permainan yang digunakan dapat diterima dengan baik oleh peserta didik. Mahasiswa sebagai calon guru juga penting memiliki kemamuan dalam mengembangan jenis-jenis permainan yang dapat digunakan dalam pembelajaran. Mahasiswa pendidikan fisika memang sudah selayaknya memiliki kemampuan untuk mengembangkan jenis-jenis permainan dala pembelajaran karena banyak fakta yang menunjukkan bahwa pembelajaran pada mata pelajaran fisika dibanyak tempat menunjukkan kondisi yang kurang menyenagkan. Hal ini erat kaitanya dengan mata pelajaran fisika yang banyak memberikan kesan kaku karena hanya disajikan dengan rumus dan agka-angka. Kondisi ini dipertegas dengan kebanyakan pendidik dalam bidang fisika yang berusaha menyampaikan fisika seperti mata pelajaran yang berat dan kaku. Oleh karena itu memang layak jika calon guru memiliki kemampuan dalam mengembngakan permainan dalam pebelajaran.

\section{REFERENSI}

(1) Murtiningsih, 2013. "Video Games dan Filsafat Pendidikan: Pendekatan Teori Simulacra Jean Baudrillad". Prosiding the 4th international conference on indonesian studies : "Unity, Diversity, and Future", Lhoksumawe. 2013.

(2) Purwanto, 2011. "Pentingnya Kreativitas Guru dan Calon Guru Fisika SMA Dalam Upaya Pengembangan dan Pengadaan Alat Demonstrasi/ Eksperimen Untuk Menjelaskan Konsep Dasar Fisika ".Prosiding Seminar Nasional Penelitian, Pendidikan dan Penerapan MIPA, Fakultas MIPA, Universitas Negeri Yogyakarta. 2011. 
(3) Sigid. $2014 . \quad$ "Upaya Meningkatkan Hasil Belajar Sepak Takraw Melalui Permainan Krawnis Pada Siswa Kelas V SDN 01 Depok Kecamatan Siwalan Kabupaten Pekalongan Tahun 2013”. Journal of Physical Education, Sport, Health and Recreations .984-988.

(4) Triwiyono. 2011. Program Pembelajaran Fisika Menggunakan Metode Eksperimen Terbimbing Untuk Meningkatkan Keterampilan Berpikir Kritis. Jurnal Pendidikan Fisika Indonesia, 7: 80-83. 